\title{
The prevalence and molecular characterisation of blood parasites infecting the vulnerable Tamarugo Conebill (Conirostrum tamarugense) and other birds in the Pampa del Tamarugal, Chile
}

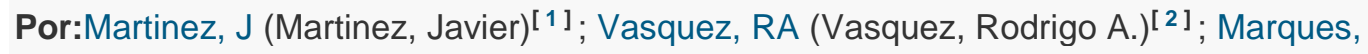
A (Marques, Alberto) ${ }^{[1]}$; Diez-Fernandez, A (Diez-Fernandez, Alazne) ${ }^{[3]}$; Merino, S (Merino, Santiago) ${ }^{[2]}$

Ver ResearcherID y ORCID

EMU

Volumen: 116

Número: 3

Páginas: $310-314$

DOI: $10.1071 / \mathrm{MU15090}$

Fecha de publicación: JUL 2016

Ver información de revista

\section{Resumen}

Blood parasites exert significant selective pressure, which can alter population dynamics, and the introduction of new parasite lineages in a region could lead to the extinction of endemic avian species that have not coevolved with them. The avifauna of the Pampa del Tamarugal in the desert of Atacama, Chile, is highly depauperate, with two species accounting for the greatest numbers: the widespread Rufous-collared Sparrow (Zonotrichia capensis) and the endemic Tamarugo Conebill (Conirostrum tamarugense). We used molecular and microscopic methods to estimate the prevalence of haemoparasites in birds inhabiting the Pampa del Tamarugal. The molecular screening of the samples from the most common species indicated that the Tamarugo Conebill was only infected by parasites of the genus Leucocytozoon (prevalence 3.5\%) and the Rufous-collared Sparrow was uninfected. Only two other bird species (of a total of seven) were infected, the House Sparrow (Passer domesticus), by Plasmodium relictum (prevalence 30\%), and the Eared Dove (Zenaida auriculata), by Haemoproteus multipigmentatus (prevalence 100\%). The occurrence of House Sparrows infected with the Plasmodium haplotype GRW4 (involved in Hawaiian bird extinctions) may entail the risk of potential host-switching, something particularly relevant for the conservation of the endemic and vulnerable Tamarugo Conebill.

\section{Palabras clave}

Palabras clave de autor:avian malaria; haplotype GRW4; host-switching; House

Sparrow; Plasmodium; Leucocytozoon

KeyWords Plus:AVIAN MALARIA; HAEMOSPORIDA HAEMOPROTEIDAE; PLASMODIUMRELICTUM; NATURAL-HISTORY; PASSERINE

BIRDS; DIVERSITY; HEMATOZOA; AMERICA; HAWAII 


\section{Información del autor}

Dirección para petición de copias: Martinez, J (autor para petición de copias)

$+\quad$ Univ Alcala De Henares, Fac Farm, Dept Biomed \& Biotecnol, Area Parasitol, E-28871 Madrid, Spain.

Direcciones:

+ [1 ] Univ Alcala De Henares, Fac Farm, Dept Biomed \& Biotecnol, Area Parasitol, E-28871 Madrid, Spain

+ [2] Univ Chile, Inst Ecol \& Biodiversidad, Fac Ciencias, Dept Ciencias Ecol, Santiago 3425, Chile

+ [ 3 ] CSIC, Museo Nacl Ciencias Nat, Dept Ecol Evolut, J Gutierrez Abascal 2, E-28006 Madrid, Spain

Direcciones de correo electrónico:francisco.martinez@uah.es

Financiación

\begin{tabular}{|c|c|}
\hline Entidad financiadora & $\begin{array}{l}\text { Número de } \\
\text { concesión }\end{array}$ \\
\hline Spanish Ministry of Science and Technology & CGL2009-09439 \\
\hline Spanish Ministry of Economy and Competiveness & $\begin{array}{l}\text { CGL2012-40026-C02- } \\
01 \\
\text { CGL2012-40026-C02- } \\
02\end{array}$ \\
\hline Fundacion BBVA & BIOCON06/109 \\
\hline $\begin{array}{l}\text { Fondo Nacional de Desarrollo Cientifico y Tecnologico (FONDECYT- } \\
\text { Chile) }\end{array}$ & 1090794 \\
\hline Fondo Nacional de Desarrollo Cientifico y Tecnologico (FONDECYT) & 1140548 \\
\hline Institute of Ecology and Biodiversity & $\begin{array}{l}\text { ICM-P05-002-Chile } \\
\text { PFB-23-CONICYT-Chile }\end{array}$ \\
\hline
\end{tabular}

Ver texto de financiación

\section{Editorial}

CSIRO PUBLISHING, UNIPARK, BLDG 1, LEVEL 1, 195 WELLINGTON RD, LOCKED BAG 10, CLAYTON, VIC 3168, AUSTRALIA

\section{Categorías / Clasificación}

Áreas de investigación:Zoology

Categorías de Web of Science:Ornithology

\section{Información del documento}

Tipo de documento:Article

Idioma:English

Número de acceso: WOS:000381431100011

ISSN: 0158-4197 
eISSN: $1448-5540$

\section{Información de la revista}

- Impact Factor: Journal Citation Reports ${ }^{\circledR}$

Otra información

Número IDS: DT4DU

Referencias citadas en la Colección principal de Web of Science: 35

Veces citado en la Colección principal de Web of Science: 0 